\title{
What Accounts for China's Trade Balance Dynamics?
}

\section{Yin Zhang * and Guanghua Wan *}

August 2004

\begin{abstract}
This paper proposes a structural VAR model which extends the frameworks of Hoffmaister and Roldós (2001) and Prasad (1999). The model is then used to analyse the sources of China's trade balance fluctuations in the period of 1985-2000. Efforts are made to distinguish the forces which underlie the long-run trend in trade balance from those with transitory impacts. The effects of four types of shock are examined-the foreign supply shock, the domestic supply shock, the relative demand shock, and the nominal shock. Among other findings, two emerge as important. First, the movements in China's trade are largely the result of real shocks. Second, the Renminbi is undervalued, yet changes in the exchange rate bear little on the trade balance. Therefore, monetary measures would not suffice to redress China's trade 'imbalance'.
\end{abstract}

Keywords: China, trade balance, real exchange rate, structural VAR, Law of One Price

JEL classification: O53; F40; E0

Copyright @ UNU-WIDER 2004

* Both authors: World Institute for Development Economics Research, United Nations University (UNU-WIDER), Helsinki, Finland.

This study has been prepared within the UNU-WIDER internship programme and research on 'New Directions in Development Economics'.

UNU-WIDER acknowledges the financial contributions to the research programme by the governments of Denmark (Royal Ministry of Foreign Affairs), Finland (Ministry for Foreign Affairs), Norway (Royal Ministry of Foreign Affairs), Sweden (Swedish International Development Cooperation Agency-Sida) and the United Kingdom (Department for International Development). 
The World Institute for Development Economics Research (WIDER) was established by the United Nations University (UNU) as its first research and training centre and started work in Helsinki, Finland in 1985. The Institute undertakes applied research and policy analysis on structural changes affecting the developing and transitional economies, provides a forum for the advocacy of policies leading to robust, equitable and environmentally sustainable growth, and promotes capacity strengthening and training in the field of economic and social policy making. Work is carried out by staff researchers and visiting scholars in Helsinki and through networks of collaborating scholars and institutions around the world.

www.wider.unu.edu publications@wider.unu.edu

UNU World Institute for Development Economics Research (UNU-WIDER)

Katajanokanlaituri 6 B, 00160 Helsinki, Finland

Camera-ready typescript prepared by Adam Swallow at UNU-WIDER

Printed at UNU-WIDER, Helsinki

The views expressed in this publication are those of the author(s). Publication does not imply endorsement by the Institute or the United Nations University, nor by the programme/project sponsors, of any of the views expressed. 


\section{Introduction}

China's rapid rise to a major trading nation in the world has attracted increasing attention in the economics literature. Much work focused on the price elasticities of imports and exports. The balance of evidence from these elasticity estimations suggests that domestic and foreign incomes exert greater impact on imports, exports and the trade balance than do changes in exchange rates (Zhang, 1996; Cerra and Dayal-Gulati, 1999; Ahearne, Fernald and Loungani, 2001). Others argued that reforms in the external sector have contributed significantly to the growth of the trade volume, particularly the growth of exports. These reforms have improved the conformity of China's trade pattern with its comparative advantage (Yue and Hua, 2002), induced larger inflows of foreign direct investment (Liu, Wang and Wei, 2001), and resulted in reductions of implicit export tax (Zhang, 2001a).

Previous studies provide some insights into the determinants of China's trade balance. However, they fail to distinguish between structural factors that would shape China's trade pattern for years to come and factors with only temporary effects on the trade balance. Such a distinction is important on a number of grounds. First, China has been running a current account surplus since 1994. This contradicts the prediction of standard economic theory that the current account of a fast-growing low income economy should be in deficit. Since the bulk of the current account surplus has been the trade surplus, it is important to assess whether the recent movements in the trade balance can be sustained or are only a temporary phenomenon. Second, the role played by the (nominal as well as real) exchange value of the Chinese currency, Renminbi (RMB), continues to cause controversy in both the academic circle and the political arena. In the aftermath of the Asian financial crisis, it was disputed whether the 1994 devaluation of the RMB improved China's trade balance at the expense of neighbouring economies, and thus should take the blame for triggering the crisis. Lately, there have been arguments about whether China is pursuing a mercantilist beggar-thy-neighbour policy by keeping the RMB undervalued. The manipulation of the nominal exchange rate cannot change the structural component of the trade balance, but may nonetheless produce predominant short-run impact. An examination of the relative importance of short-run factors against structural factors in affecting the trade balance has a direct bearing on the ongoing debate on China's exchange rate policy. Third, international trade transmits business cycle fluctuations across national borders. To evaluate the scope of cushioning against adverse foreign shocks through domestic monetary (and exchange rate) policy, it is necessary to compare the relative strength of the effects of short-run and structural factors over different horizons.

This paper analyses the sources of China's trade balance fluctuations in the period of 1985-2000. To distinguish factors causing shifts in the long-run trend of the trade balance from those with only temporary effects, we employ the strategy of Blanchard and Quah (1989) who use long-run restrictions to identify vector auto-regression (VAR) models. Our approach is similar to those in Hoffmaister and Roldós $(1999,2001)$ and Prasad (1999). However, their analyses presume the long-run validity of the Law of One Price (LOP), which states that commodity arbitrage would eventually bring into line the prices of tradable goods across national borders (when these prices are expressed in the same currency). This requires that the effects of nominal shocks on the real exchange 
rate vanish over time. As a result, Hoffmaister and Roldós $(1999,2001)$ did not analyse the dynamic interactions between the real exchange rate and the trade balance because the long-run effects of exogenous shocks on these two variables are indistinguishable in their model. Prasad (1999) included both variables in his model, but achieved identification only by adding an additional assumption-hysteresis in the trade balance. Due to the lack of robust empirical support for both the LOP and trade hysteresis, we propose a near-VAR in this paper, which is identified by relaxing the LOP assumption. This renders our model more general and particularly suitable for situations where, for example, there exist significant trade barriers, the span of data is short, or the main concern is with the medium run rather than the analytical long run. Furthermore, it enables us to assess the recent contention that a nominal revaluation would, via correcting the undervaluation of the RMB, redress China's trade imbalance.

The rest of the paper is organised as follows. The next two sections describe, respectively, the methodology and data set. Section 4 reports and discusses the results and the last section concludes.

\section{Methodology}

Consider a VAR of four variables: the real output of trading partners $\left(y^{*}\right)$, domestic real output $(y)$, the trade balance $(b)$, and the real exchange rate $(q) .{ }^{1}$ The moving-average form of the structural model is given by

$$
\Delta \mathbf{x}_{t}=A(L) \boldsymbol{\varepsilon}_{t},
$$

where $\mathbf{x}^{\prime}=\left[y^{*}, y, b, q\right]^{\prime}, \Delta$ is the first-difference operator, $A(L)$ is a matrix polynomial in the lag operator $L$, and $\boldsymbol{\varepsilon}$ is the vector of the four structural shocks: foreign supply shock $\left(\varepsilon^{f}\right)$, domestic supply shock $\left(\varepsilon^{s}\right)$, relative demand shock $\left(\varepsilon^{d}\right)$ and nominal shock $\left(\varepsilon^{n}\right)$. Note that the constant terms are suppressed to simplify the notation.

Write the reduced form of equation (1) as $\Delta \mathbf{x}_{t}=C(L) \mathbf{e}_{t}$, where $\boldsymbol{\varepsilon}_{t}=G^{-1} \mathbf{e}_{t}$, $\mathbf{e}_{t} \square \operatorname{iid}(0, \Sigma), A(L)=C(L) G$ and $G$ is a $4 \times 4$ non-singular matrix. The parameters in $\Sigma$ and $C(L)$ can be obtained by estimating the VAR

$$
D(L) \Delta \mathbf{x}_{t}=\mathbf{e}_{t},
$$

where $C(L)=D^{-1}(L)$. The key to recovering $A(L)$, therefore, lies with the identification of $G$, for which a total of 16 restrictions are required. Upon normalising the variances of the structural shocks to unity and assuming that they are mutually orthogonal, the relationship $\left.\Sigma=E(\mathbf{e e})^{\prime}\right)=G E(\mathbf{\varepsilon \varepsilon}) G^{\prime}=G G^{\prime}$ provides 10 independent restrictions.

1 Lower case letters represent the logarithmic form of the corresponding variable unless otherwise indicated. 
To derive the remaining six identification restrictions, we follow Hoffmaister and Roldós (2001) by assuming that the model economy produces tradables and nontradables with the production technologies described by

$$
Y_{T, t}=A_{T, t} K_{t}^{1-\alpha} L_{T, t}^{\alpha}
$$

and

$$
Y_{N, t}=A_{N, t} L_{N, t}^{\beta},
$$

where the subscripts $T$ and $N$ denote respectively the tradables and non-tradables sectors, the $Y$ s represent the units of output, the $A$ s are time-varying technology parameters, and $0<\alpha, \beta<1$. As the non-tradables sector is typically less capital-intensive than the tradables sector, tradables are produced with both labour (denoted by $L$ ) and capital (denoted by $K$ ), while the production of non-tradables requires merely one inputlabour. Households in the economy consume both goods. The optimisation problem of a benevolent social planner can be written as

$$
\max U_{t}=E_{t} \sum_{i=t}^{\infty}\left\{\left(\frac{1}{1+\rho}\right)^{i-t}\left[\delta \log C_{T, i}+(1-\delta) \log C_{N, i}\right]\right\}
$$

subject to resource constraints and

$$
D_{t+1}=r^{*} D_{t}+Y_{t}-C_{T, t}-\left(P_{N, t} / P_{T, t}\right) C_{N, t},
$$

where $E$ is the expectation operator, the $C$ s represent the units of consumption, $\rho$ is the subjective discount rate, $Y_{t}$ denotes total output measured in tradables, $P_{T}$ and $P_{N}$ are the prices of the tradables and non-tradables respectively, $D_{t}$ is the stock of foreign assets carried over from period $t-1, r^{*}$ is the world interest rate, and $\delta$ is the share of expenditure on tradables in a utility-maximising consumption bundle. The cost-of-living index $P$ can be expressed as 2

$$
P \equiv \frac{P_{T}^{\delta} P_{N}^{1-\delta}}{\delta^{\delta}(1-\delta)^{1-\delta}}
$$

Let $P^{*}$ be the reciprocal foreign price index, and the nominal exchange rate $S$ be the value of foreign currency in terms of domestic currency. Then, a rise in the real exchange rate $Q\left(\equiv S P^{*} / P\right)$ represents a fall in the international purchasing power of domestic currency. The (logarithmic) real exchange rate can be decomposed as

$$
q=\Phi_{1}+s+p_{T}^{*}-p_{T}+(1-\delta)\left(p_{T}-p_{N}\right)-\left(1-\delta^{*}\right)\left(p_{T}^{*}-p_{N}^{*}\right)
$$

2 This is the minimum expenditure on one unit of the composite consumption $C_{T}^{\delta} C_{N}^{1-\delta}$. 
where $\Phi_{1}$ consists of $\delta$ and $\delta^{*}$ only. ${ }^{3}$ Productivity growth in the tradables sector is determined by

$$
A_{T, t}=\left(Y_{t}^{*}\right)^{\theta}
$$

where $Y^{*}$ is the level of foreign output and $\theta$ measures the ability of the domestic economy to absorb foreign technology.

Given the above model, it can be shown that the steady-state value of $q$ is given by 4

$$
\bar{q}=\Phi_{2}+s+p_{T}^{*}-p_{T}+(1-\delta)\left[\left(a_{N}-\frac{1}{\alpha} a_{T}\right)-(1-\beta) \log (1-\bar{\lambda})\right]
$$

where the letters with over-bars denote steady-state values, $\lambda$ is the share of labour employed in the tradables sector (i.e., $\lambda \equiv L_{T} /\left(L_{T}+L_{N}\right)$ ), and $\Phi_{2}$ is made up of preference and technology parameters and exogenous variables (i.e., total labour supply $L$ and $r^{*}$ ). The steady-state value of $\lambda$ is

$$
\bar{\lambda}=\frac{(1-\alpha) \delta}{\beta r^{*}+(1-\alpha) \delta} .
$$

It is clear from equations (10) and (11) that the long-run value of the real exchange rate is affected by both supply side factors and demand side factors. On the supply side, the effects of productivity disturbances in the tradables sector (shocks to $a_{T}$ ) and those in the non-tradables sector (shocks to $a_{N}$ ) are not symmetrical. Even balanced productivity growth in the two sectors will lead to real appreciation (i.e., a decline in $q$ ). This is the 'productivity bias' emphasised by the Balassa-Samuelson hypothesis (Balassa, 1964; Samuelson, 1964).

On the demand side, a shift in the intratemporal preference from non-tradables to tradables (a rise in $\delta$ ) depresses the relative price of the non-tradables, thus leading to real depreciation and a reallocation of labour to the tradables sector. Hoffmaister and Roldós (2001) identify this shock with changes in government consumption, assuming that government consumption is weighted heavily towards non-tradables. It appears to us that this definition of the shock is of limited applicability and perhaps not appropriate for characterising the Chinese economy. During our sample period 1985-2000, the ratio of annual government consumption to GDP in China has a standard deviation of 0.7 per cent, with the coefficient of variation at 5.8 per cent. 5 Both would put China at the lower end of the variability scale of government consumption. On the other hand, rapid income growth and profound changes to the social welfare system provide ample

3 Hereafter the foreign variables are distinguished from their domestic counterparts by the asterisk.

4 See Appendix A for the derivation of the solution to the model.

5 The two statistics are calculated using government consumption and GDP data from International Financial Statistics 2002. 
opportunity for shifts in the aggregate demand structure to occur.6 Therefore, we replace the government consumption shock with a more inclusive relative demand shock $\left(\varepsilon^{d}\right)$, that is, disturbances to the preference of tradables over non-tradables.

A second and more important departure in equation (10) lies in its allowing for the possibility that deviations from the LOP may persist for a long time. That is, the effects on the real exchange rate of the temporary shock $\left(\varepsilon^{n}\right)$, which we interpret as mainly of a monetary origin, are not restricted either in the long run or in the short run. Unlike the Hoffmaister-Roldós model which attributes the non-stationarity of the real exchange rate entirely to changes in the relative price of non-tradables to tradables within border, sustained movements in the relative price of tradables across border are allowed to play a part in our model. Thus, we are able to include the trade balance and the real exchange rate in the same VAR model and identify the structural shocks without resorting to additional restrictions, which is not the case in the Hoffmaister-Roldós model. In this aspect, our model resembles that of Prasad (1999) who also examines the joint dynamics of the real exchange rate and the trade balance. However, Prasad achieves identification by appealing to hysteresis in the trade balance rather than relaxing the assumption of long-run LOP. Our identification scheme is preferable because the evidence on the empirical relevance of trade hysteresis is far from conclusive (Parsley and Wei, 1993; Campa, 2000). Meanwhile, a large body of empirical literature has documented persistent deviations from the LOP for a wide range of tradable goods even among countries where transaction costs and trade barriers are supposedly low (Rogers and Jenkins, 1996; Engel, 1999). Even if the LOP does attain in the long run, it is often the medium-range horizons (5-10 years), during which deviations prevail, that are of special concern to policy-making. In developing and transition economies, in particular, government interventions and market imperfections may disrupt the parallel between changes in the nominal exchange rate and price differentials between domestic and foreign tradables for an extended period. For instance, Polterovich and Popov (2002) present evidence that China and several other fast-growing economies accumulated large stocks of foreign exchange reserves without triggering high inflation. This type of sterilized intervention in the foreign exchange market attenuates the linkage between the nominal exchange rate and the price of tradables in domestic currency. The case for the LOP is further weakened.

In the steady state, the current account balances so that the economy maintains a constant stock of foreign assets. Hence, the steady-state value of the trade balance is $\bar{B}=\bar{Y}_{T}-\bar{C}_{T}=r^{*} \bar{D}$. As shown in Appendix A, the logarithm of $\bar{B}$ can be expressed as

$$
\bar{b}=\Phi_{3}+(1 / \alpha) a_{T}+\log \bar{\lambda}
$$

where $\Phi_{3}$ is a function of $\alpha, r^{*}$ and total labour supply. Productivity growth in the tradables sector increases the economy's ability to carry foreign debts to finance capital accumulation. This, in turn, requires a larger trade surplus in the steady state. Similarly, higher relative demand for tradables increases trade surplus as it stimulates capital accumulation and attracts labour into the tradables sector.

6 Bergstrand (1991) presents a model where non-homothetic tastes generate different income elasticities of demand for tradables and non-tradables. 
The steady-state value of total output $Y$ is largely supply-determined. A positive shock to $\delta$ not only increases tradables output at the expense of non-tradables output, but also lowers the relative price of non-tradables. Its total effect on $Y$ depends on the relative magnitude of $\alpha$ and $\beta$. Where labour income shares in the two sectors do not diverge significantly, 7 a relative demand shock has virtually no long-run effect on $Y$. In any case the effect on $y$ is likely to be substantially smaller than that on $q$ (Hoffmaister and Roldós, 1999). It is also implied in the above discussion that domestic economy is not sufficiently large to affect the rest of the world (i.e., $Y^{*}$ and $r^{*}$ ). Therefore, the long-run impact matrix of the structural shocks in equation (1) is lower triangular, or

$$
\left[\begin{array}{c}
\bar{y}^{*} \\
\bar{y} \\
\bar{b} \\
\bar{q}
\end{array}\right]=A(1) \boldsymbol{\varepsilon}_{t}=\left[\begin{array}{cccc}
a_{11}(1) & 0 & 0 & 0 \\
a_{21}(1) & a_{22}(1) & 0 & 0 \\
a_{31}(1) & a_{32}(1) & a_{33}(1) & 0 \\
a_{41}(1) & a_{42}(1) & a_{43}(1) & a_{44}(1)
\end{array}\right]\left[\begin{array}{c}
\varepsilon^{f} \\
\varepsilon^{s} \\
\varepsilon^{d} \\
\varepsilon^{n}
\end{array}\right] \text {, }
$$

where the $a_{i j}$ 's $(i, j=1, \ldots, 4)$ are polynomials in the lag operator $L$. The three zeros in the first row of $A(1)$ follow directly from the small open economy assumption. Treating China as a small economy may cause some concern. However, as it will become clear below, all this requires in our empirical analysis is that a weighted average of the total import volumes of China's major trading partners is not affected by developments inside China. Considering that these countries include the US, Japan and Germany, this is not an unreasonable assumption. Nonetheless, we test this assumption in section 4. The second row of the matrix indicates that only foreign and domestic supply shocks, corresponding to productivity shocks in the tradables and non-tradables sectors respectively, are allowed to have long-run effects on domestic output. The third row restricts to zero the long-run effect of nominal shocks on the trade balance. Thus, longrun nominal neutrality is maintained for output and the trade balance. It is, however, not invoked with respect to the real exchange rate.

\section{Data}

Our empirical model is estimated over the period of 1985-2000. Quarterly observations are used to capture short-run dynamics. Because real GDP and industrial production data are only available for a limited period for several of China's important trading partners, the foreign output variable, $Y^{*}$, is proxied by the trade-weighted average of the import volumes of the largest sixteen trading partners. Domestic total output, $Y$, is substituted for by the gross value of domestic industrial production since quarterly GDP data are not available for the years before 1994. The series used as the real exchange rate, $Q$, is a trade-weighted and consumer price index-adjusted index-the real effective exchange rate (REER). The proxy for the trade balance is the ratio of exports to imports, $T R .8$ See Appendix B for more information about the data.

7 The ratio of labour income shares of non-tradables to tradables sector is 0.918 in Mendoza (1995).

8 In the business cycle literature, the ratio of real trade balance to real GDP is often used to measure trade balance (Agénor, McDermott and Prasad, 2000). Bahmani-Oskooee (1991) argues that for 
It is commonly believed that the exchange rate may be used as a stabilisation tool provided that prices are sticky. However, the efficacy of that tool depends on how synchronised domestic business cycles are with international business cycles, as well as on the responsiveness to exchange rate movements of the demand for and supply of exports and imports. Since we are particularly interested in the role of the real exchange rate in explaining trade balance fluctuations, we conduct some preliminary analysis to explore how the relationship might pan out in the Chinese context.

To assess the correlation between China's business cycles and those of its trading partners, the cyclical components of the constructed import index and China's industrial production are plotted in Figure 1.9 Fluctuations in the foreign import series are of smaller amplitude than those in domestic industrial production. This is not surprising given that the former is essentially the average of a number of unsynchronized series. The figure also suggests that the conformity of China's business cycles with international cycles has varied over time. In the first half of the 1990s, domestic industrial production evolved quite independently; the other years saw some concordance between the two series. Accordingly, their contemporaneous correlation coefficient changed from 0.56 for $1985-90$ to 0.05 for 1991-96 to 0.57 for 1997-2000.

Figure 1 Cyclical components of foreign imports and domestic industrial production

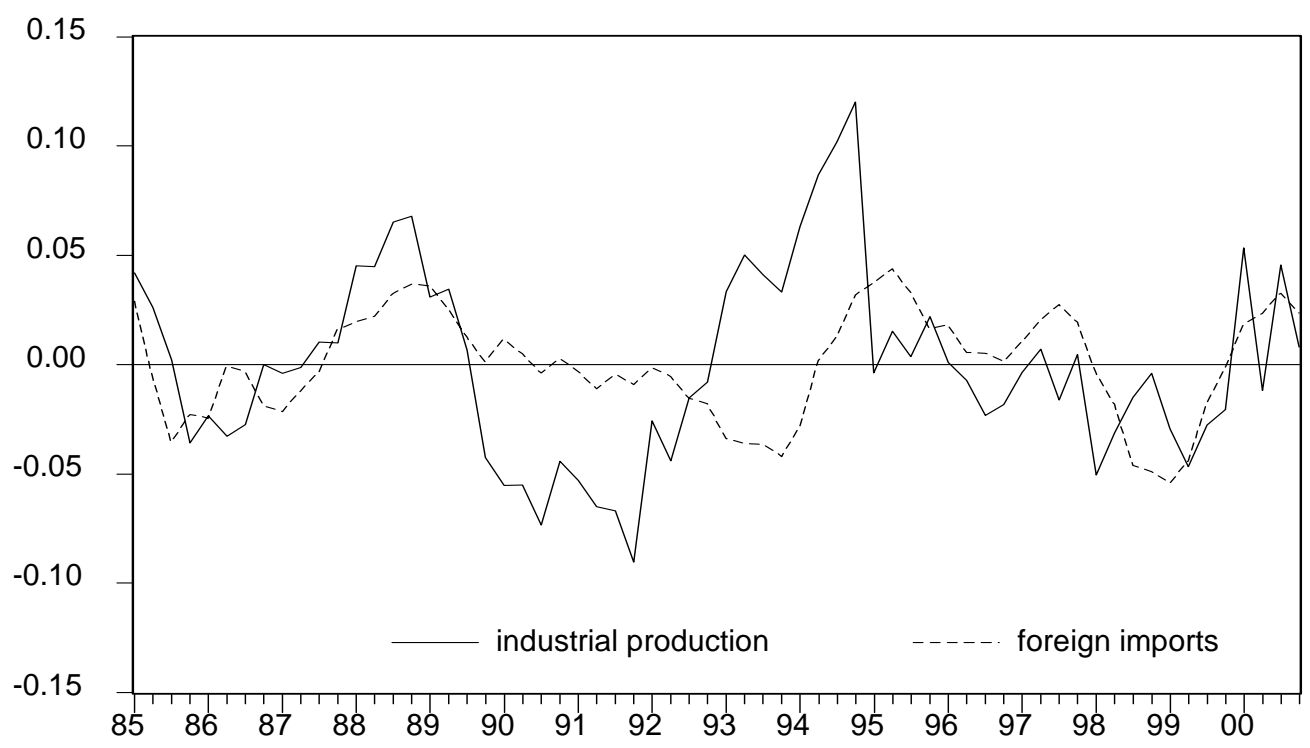

developing economies where reliable price data are not available the exports/imports ratio makes a good alternative as it is invariant to the choice of price indices. It is also used to measure the US trade balance in Haynes and Stone (1982).

9 The cyclical components are extracted by the Hodrick-Prescott filter with $\lambda=1600$. 


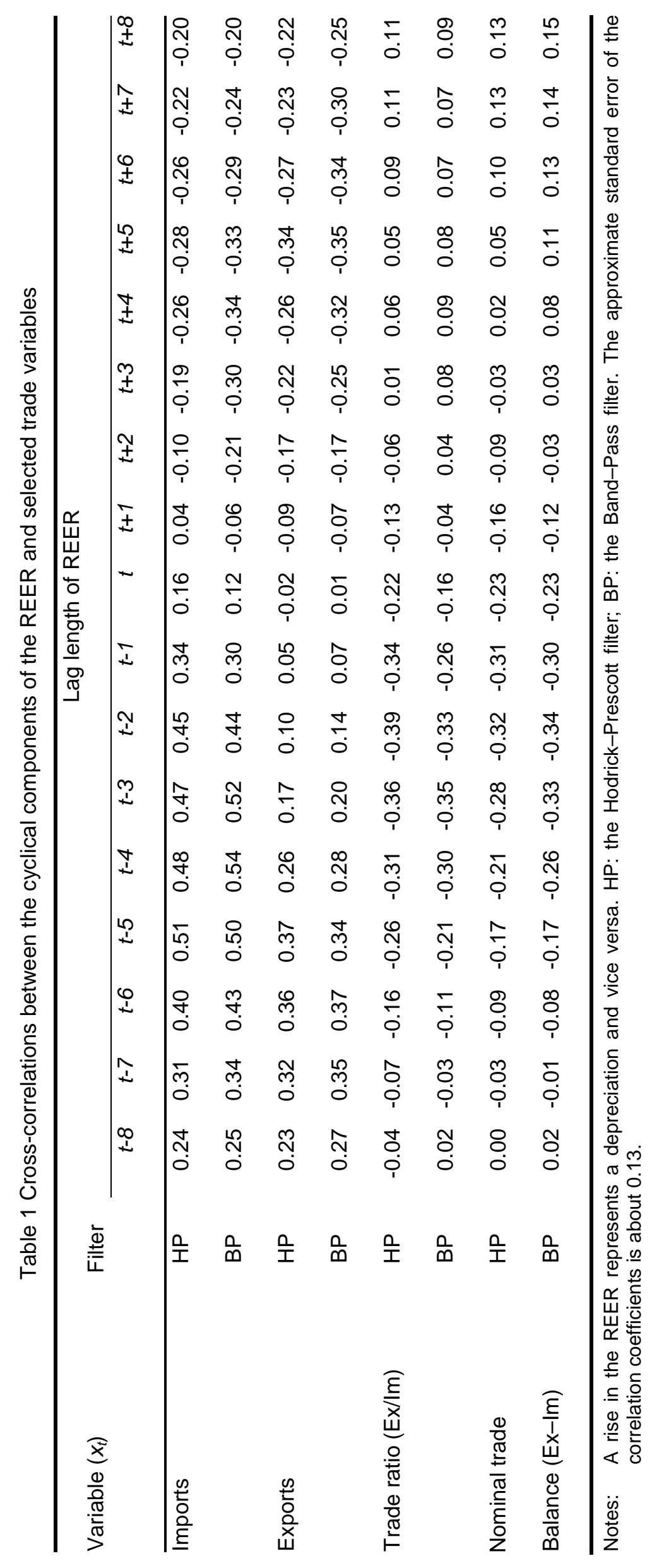


We also compute the correlation coefficients between the cyclical components of the REER and several trade variables at various leads and lags (see Table 1). Contemporaneously, none of the trade variables is significantly correlated with the REER. Although the REER tends to lead the trade variables, 10 the signs of the correlation coefficients at the lags of the REER show that a real depreciation is associated positively with both exports and imports and negatively with the trade balance. This correlation pattern, even when the 'J-curve' effect is allowed for, is certainly not typical of situations where devaluations can serve as an effective tool in combating adverse trade balance.

\section{Empirical results}

To ensure that the specification in the form of equation (2) is supported by Chinese data, a series of tests are performed. The first one tests the four series representing $y^{*}, y, b$ and $q$ for unit roots. As the results in Table A1 of Appendix B indicate, each of them can be considered as being generated by an $I(1)$ process.

Next, the Johansen procedure is applied to a standard VAR system composed of the levels of the four series. The adjusted $\lambda_{\text {trace }}$ test statistic for the VAR system is $36.70,11$ indicating that the null hypothesis of no cointegration among the series cannot be rejected at the 10 per cent significance level.

The third type of tests takes on parameter stability. We examine the possibilities of structural breaks caused by the 1994 exchange rate reform and the 1997 Asian crisis. All test statistics reported in Table 2 clearly favour the null of model stability.

Table 2 Diagnostic tests

\begin{tabular}{|c|c|c|c|c|c|}
\hline & \multicolumn{2}{|c|}{ Wald test } & \multicolumn{2}{|c|}{ Likelihood ratio test } \\
\hline & & Statistic & p-value & Statistic & $p$-value \\
\hline \multirow[t]{2}{*}{1994 devaluation } & structural break at $1993: 4$ & 3.63 & 0.46 & 4.69 & 0.32 \\
\hline & structural break at $1994: 1$ & 3.84 & 0.43 & 4.96 & 0.29 \\
\hline \multirow[t]{2}{*}{ Asian crisis } & structural break at 1997:2 & 0.11 & 0.99 & 0.17 & 0.99 \\
\hline & crisis period: 1997:2-1998:2 & 3.16 & 0.53 & 6.72 & 0.15 \\
\hline \multicolumn{2}{|c|}{ Test for exogeneity: $y^{*}$} & 7.31 & 0.61 & 8.67 & 0.47 \\
\hline
\end{tabular}

10 The largest correlation coefficients (in absolute value) appear at the lags of the REER. For example, the largest coefficient for imports using the HP filter appears at lag five of the REER (column $t-5$ ) and its value is 0.51 .

11 The VAR system has a lag length of four, which is selected in accordance with the BIC and HQ statistics. The $\lambda_{\text {trace }}$ statistic is adjusted by the small sample correction factor proposed in Reinsel and Ahn (1992). 
Table 3 Forecast error variance decomposition

\begin{tabular}{|c|c|c|c|c|}
\hline Quarters & breign supply shock & $\begin{array}{l}\text { Domestic supply } \\
\text { shock }\end{array}$ & $\begin{array}{l}\text { Relative demand } \\
\text { shock }\end{array}$ & Nominal shock \\
\hline & \multicolumn{4}{|c|}{ Forecast error variance of $\Delta y$} \\
\hline 1 & $6.20 \quad(1.52,20.21)$ & $66.40(36.81,80.85)$ & $2.58(0.30,17.41)$ & $24.81 \quad(3.87,43.27)$ \\
\hline 2 & $6.44(2.99,20.96)$ & $56.89(30.59,68.97)$ & $13.22(5.23,29.34)$ & $23.45 \quad(4.69,39.39)$ \\
\hline 3 & $8.70(5.01,23.12)$ & $47.50(26.53,56.91)$ & $23.94(12.51,36.47)$ & $19.85(5.74,33.51)$ \\
\hline 4 & $9.33(5.88,24.73)$ & $43.25(24.24,51.96)$ & $29.36(15.05,41.13)$ & $18.07(6.12,31.40)$ \\
\hline 8 & $9.18(7.09,26.06)$ & $42.66(23.46,50.87)$ & $29.51(15.46,40.54)$ & $18.65(6.72,30.95)$ \\
\hline 12 & $9.21 \quad(7.17,26.14)$ & $42.50(23.12,50.72)$ & $29.73(15.44,40.72)$ & $18.57(6.87,30.93)$ \\
\hline 16 & $9.21 \quad(7.17,26.16)$ & $42.46(23.06,50.69)$ & $29.77(15.45,40.74)$ & $18.56(6.87,30.96)$ \\
\hline \multirow[t]{2}{*}{20} & $9.21 \quad(7.17,26.16)$ & $42.46(23.05,50.65)$ & $29.77(15.45,40.75)$ & $18.56(6.87,30.96)$ \\
\hline & \multicolumn{4}{|c|}{ Forecast error variance of $\Delta T R$} \\
\hline 1 & $0.27(0.06,6.15)$ & $4.21 \quad(0.43,24.43)$ & $81.90(48.61,90.11)$ & $13.62(1.47,33.66)$ \\
\hline 2 & $1.59(0.82,12.02)$ & $4.24 \quad(1.80,24.70)$ & $78.65(44.01,83.86)$ & $15.53(2.95$ \\
\hline 3 & $1.49(1.65,13.04)$ & $10.49(7.41,27.92)$ & $74.00(41.29,75.64)$ & $14.03 \quad(4.36,31.87)$ \\
\hline 4 & $3.53(3.30,17.03)$ & $10.09 \quad(7.60,27.34)$ & $72.67(40.24,72.40)$ & $13.71 \quad(4.78,29.92)$ \\
\hline 8 & $3.83(4.39,18.23)$ & $10.04 \quad(7.83,26.49)$ & $72.54(39.11,70.54)$ & $13.60(5.69,29.41)$ \\
\hline 12 & $3.85(4.46,18.52)$ & $10.03 \quad(7.83,26.52)$ & $72.54(39.05,70.40)$ & $13.59(5.77,29.44)$ \\
\hline 16 & $3.85 \quad(4.47,18.52)$ & $10.03(7.83,26.50)$ & $72.53(39.02,70.29)$ & $13.59(5.78,29.43)$ \\
\hline \multirow[t]{2}{*}{20} & $3.85(4.47,18.53)$ & $10.03(7.83,26.50)$ & $72.53(39.01,70.28)$ & $13.59(5.78,29.43)$ \\
\hline & \multicolumn{4}{|c|}{ Forecast error variance of $\Delta q$} \\
\hline 1 & $0.15(0.08,5.28)$ & $37.38(10.54,63.74)$ & $0.12 \quad(0.24,14.73)$ & $62.36(26.91,80.15)$ \\
\hline 2 & $1.57(1.03,11.58)$ & $35.54(11.30,60.08)$ & $0.49(1.25,17.00)$ & $62.40(27.33,73.18)$ \\
\hline 3 & $2.12(2.31,13.32)$ & $34.47(11.99,56.79)$ & $3.05(3.14,20.66)$ & $60.37(26.45,67.34)$ \\
\hline 4 & $2.48 \quad(3.18,14.57)$ & $31.23(13.72,50.84)$ & $3.18(4.16,20.83)$ & $63.11(29.35,63.90)$ \\
\hline 8 & $2.66 \quad(4.36,16.57)$ & $30.85(13.94,48.28)$ & $3.99(5.53,21.83)$ & $62.50(29.39,60.97)$ \\
\hline 12 & $2.68(4.44,16.91)$ & $30.83(13.92,47.91)$ & $4.10(5.75,22.00)$ & $62.39(29.36,60.71)$ \\
\hline 16 & $2.68(4.45,16.95)$ & $30.82(13.91,47.85)$ & $4.11 \quad(5.75,22.07)$ & $62.38(29.35,60.67)$ \\
\hline 20 & $2.68(4.45,16.95)$ & $30.82(13.91,47.84)$ & $4.11 \quad(5.75,22.09)$ & $62.38(29.35,60.65)$ \\
\hline
\end{tabular}

Note: Entries in parentheses are the 0.16 and 0.84 fractiles obtained through 1000 bootstrapping replications.

Finally, we test the exogeneity of the foreign imports series, the result of which constitutes the last row of Table 2. As it turns out, the lags of changes in domestic variables $y, T R$ and reer do not help explain the changes in $y^{*}$. Thus, the near-VAR specification developed in this paper appears to be statistically adequate for capturing the dynamic relationship among the variables under study.

The model is estimated using the seemingly unrelated regression (SUR) technique of Zellner (1962). The results presented below are based on a model with three lags. 12 Figure 2 depicts the dynamic responses of the domestic variables to each of the four structural shocks. Table 3 presents the results of forecast error variance decompositions. Three aspects of these results are worth noting.

12 The lag length is chosen on the basis of the BIC and HQ statistics. 


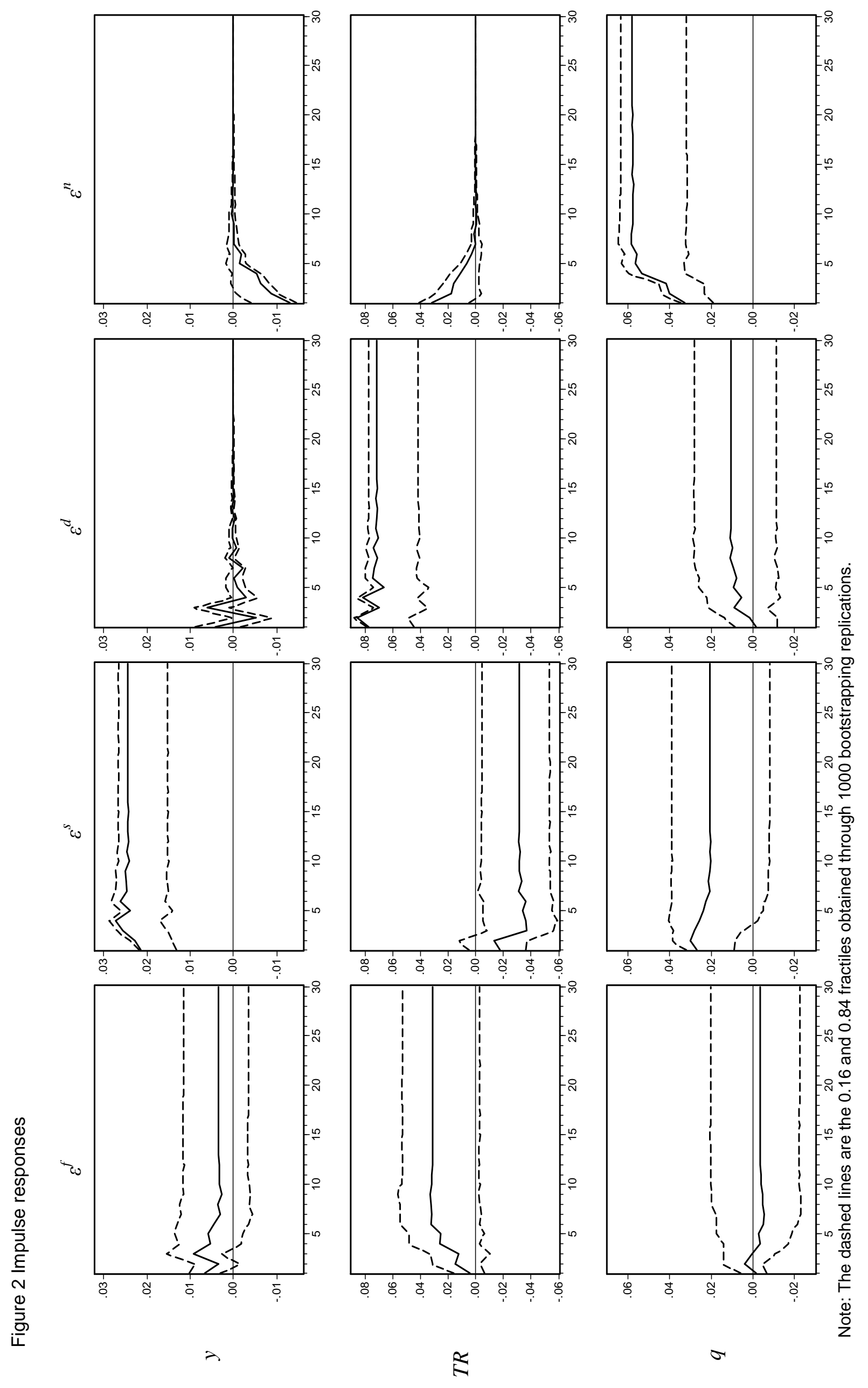




\section{Sources of fluctuations in trade balance and real exchange rate}

The decomposition of forecast error variances for the change in the trade balance identifies the relative demand shock as the driving force of fluctuations. Over 70 per cent of the total variance is due to the relative demand shock at all horizons. The importance of the domestic supply shock increases beyond the two-quarter horizon, while the foreign supply shock plays a minimal role over all horizons. In total the three real shocks explain an overwhelming majority of trade balance fluctuations. The effect of the nominal shock is appreciable but limited.

The influence of the foreign supply shock on the trade balance decreases with the labour-intensiveness of the tradables sector, and increases with the extent to which foreign technology diffuses in the domestic economy. Therefore, the finding that it is inconsequential perhaps reflects the large share of labour-intensive manufactures in China's tradable goods sector and/or the existence of considerable barriers to technology transfer. The modesty of the effect of the nominal shock suggests that the trade balance is unlikely to react strongly to changes in the nominal exchanges rate. Nor would it be much affected by domestic and foreign inflation differentials of monetary origins.

Fluctuations in the real exchange rate are almost entirely ascribable to the domestic supply shock and the nominal shock at each horizon. The nominal shock accounts for over two-thirds of the total forecast variance, which leaves about one-third explainable by the domestic supply shock in the short run and over 30 per cent in the long run. The other two shocks together explain less than 7 per cent of the total variance, with even smaller fractions in the short run.

Since the importance of the domestic supply shock much outweighs that of the foreign supply shock, at least part of the observed depreciation of the real exchange rate during the sample period can be justified as equilibrium movements. However, it is the nominal shock that dominates over all horizons. This is an indication that the RMB may have been undervalued by monetary manipulations. Indeed, several recent studies have found evidence of undervaluation for most of the sample period, though these studies differ in defining and calculating the equilibrium real exchange rate (see, among others, Bu and Tyers, 2001; Chou and Shih, 1998; Zhang, 2001b). Nonetheless, undervaluation could not have played a significant part in bringing about the rapid expansion of the trade balance. Although the two processes occurred at about the same time, our results imply that the latter had more to do with those factors that have long-lasting effects on both the trade balance and the real exchange rate, namely, shifts in tastes and productivity growth. Since these factors affect the composition and level of aggregate consumption in the long run, the recent enlargement of the trade balance should be considered to a large extent as the manifestation of changes in the 'structural' level of the trade balance.

\section{Relative income effect versus relative price effect}

As far as the trade balance is concerned, the impact of a shock often comes via several channels. The influences from these different channels may work in opposite directions. The impulse response functions plotted in Figure 2 shed light on the relative importance of different transmission mechanisms. 
In the wake of a positive foreign supply shock, the real exchange rate exhibits a moderate tendency towards appreciation due, perhaps, to the Balassa-Samuelson effect (see the first column of Figure 2). Other things being equal, this would negatively affect the trade balance. However, the trade balance actually climbs up and stabilises at a higher level after about one and a half years. Presumably, the beneficial effect stemming from increased foreign demand for and domestic supply of tradables more than offsets the effect of unfavourable exchange rate movements.

The case with the domestic supply shock is rather similar (see the second column of Figure 2). Productivity growth in the non-tradables sector lowers nominal wages, causing a real depreciation. Meanwhile, higher real domestic income induces greater demand for tradables, which is accommodated by more imports. Here again the trade balance is eroded despite the rise in the relative price of tradables to non-tradables. Nonetheless, the comparatively large depreciation occurring in the first few quarters appears to have staved off the fall of trade balance for a short period of time.

The above results support the finding in earlier studies that the relative income effect tends to exceed the relative price effect in magnitude (as mentioned in section 1). As the impulse response functions of the relative demand shock demonstrate, however, the relative price effect can still be important in the absence of changes in relative income (see the third column of Figure 2). In line with the prediction of the model presented in section 2 , a relative demand shock favouring tradable goods depresses the relative price of non-tradables while domestic output barely responds. Significant increases in the trade balance ensue consequently.

The last column of Figure 2 shows that a nominal shock, when generating a real depreciation, is followed by a substantial increase in the trade balance. The improvement of trade balance dwindles quickly, while the depreciation of the real exchange rate firms up and endures. In this case the improvement of the trade account takes place alongside a real depreciation. Notwithstanding, the timing of their occurrence - that the trade surplus diminishes while depreciation proceeds furtherraises doubts about whether the latter causes the former. In any event, the improvement of trade balance could hardly be the sole result of expenditure switching. As domestic output is contracting in the meantime, the trade balance would surely be helped by the effect of expenditure reduction (due to weaker domestic demand).

Hence, although our results are in broad agreement with previous research on the issue of relative income effect versus relative price effect, they also point to the need for distinguishing between the relative price of tradables to non-tradables and the relative price of foreign to domestic tradables (when expressed in the same currency). While an increase in either leads to a real depreciation, the former has more important implications for the trade balance than does the latter. That such a distinction is substantive calls for caution in interpreting the movements in real exchange rates calculated using indiscriminative price indices such as the consumer price index. It should also be noted that the lack of expenditure switching following a nominal shock is not necessarily attributable to weak substitution between domestic and foreign tradables. As nominal shocks account for most of the volatility in the real exchange rate, the pass-through from changes in the nominal exchange rate to the price of tradables (or the other way around) seems rather sluggish. Thus, the trade balance, and for that matter, total output, would not respond strongly to a nominal shock even if the demand for tradables is sensitive to price changes. 


\section{Business cycle synchronisation}

The impulse responses of domestic output show that the effects of the foreign supply shock are dwarfed by those of the three domestic shocks, especially the domestic supply shock. Accordingly, the foreign supply shock accounts for around 6 per cent of output fluctuations in the short run and about 9 per cent over longer horizons (see the first panel of Table 2). The domestic supply shock, on the other hand, proves to be the major source of output fluctuations, explaining nearly half of the total forecast error variance in the short run and over 40 per cent in the medium to long run. The relative demand shock comes second, accounting for just under 30 per cent of the variance. Even the contribution of the nominal shock is more than twice that of the foreign supply shock.

The dominance of domestic shocks in explaining the variability of output corroborates on the finding in section 3 that domestic and international business cycles are only weakly correlated. This can be ascribed, in part, to the pattern of China's foreign trade. The higher the share of intra-industry trade is, the stronger the transmission of industryspecific shocks, and thus the more synchronised the business cycles will be between trading partners (Frankel and Rose, 1998). Because the pattern of trade between two economies largely depends on the similarity of their industrial structures, our result can be interpreted as side evidence that the specialisation of tradables production between China and its major trading partners is more of the inter-industry type. This is consistent with the fact that large disparities in factor endowments exist between China and its major trading partners - the US, Japan, the newly industrialised economies (Hong Kong, Korea, Singapore and Taiwan), and the EU countries.

Another noteworthy result concerning domestic output is that a nominal shock leading to a real depreciation produces a mild recession. Thus, there does not seem to be much scope for counter-cyclical monetary (and exchange rate) policy. This result is at odds with the prediction of standard open economy models (e.g., Dornbusch, 1988) that devaluations are expansionary if only in the short run. However, contractionary devaluations have long been noted and documented (see, among others, Krugman and Taylor, 1978 and Edwards, 1986). We do not delve into its causes in this paper, but leave it for future research.

\section{Conclusion}

The factors responsible for movements in the trade balance fall into two groups. Some alter the trade balance permanently and thus determine the level of 'structural' trade balance. Others have their effects last only for a limited period of time. Accordingly, part of the trade balance movements can be seen as transitional dynamics between different levels of 'structural trade balance', and the rest are cyclical fluctuations that will be corrected over time. Interpreting trade balance movements within such a framework is important for macroeconomic policy formulation since these two types of movements require policy responses of distinct nature. This paper has examined, in this spirit, the movements in China's trade balance during the period of 1985-2000. The analysis is based on empirical evidence obtained from a structural near-VAR. By invoking the long-run properties of a two-sector small open economy model, we apportion trade balance fluctuations to four types of exogenous shocks which can be associated respectively with productivity growth in the tradables and non-tradables 
production, shifts in preference between tradables and non-tradables, and nominal disturbances stemming from changes in the nominal exchange rate or domestic money markets.

Our results suggest that the movements in China's trade balance are first and foremost the result of real shocks. In this sense most of the enlargement of China's trade balance in the past two decades should be considered as 'structural', and thus would not be amenable to being altered by monetary measures. Furthermore, between relative income (at home versus abroad) and relative price (non-tradables to tradables and domestic to foreign tradables), the effects of changes in relative income are more likely to prevail. This indicates that the trade pattern between China and its major trading partners is more complementary than competitive. It is therefore advisable to caution against overplaying the causation from exchange rate movements to changes in the trade balance.

On the other hand, it is found that nominal shocks do leave substantial imprint on the real exchange rate, lending some support to the argument that the RMB is undervalued by government intervention. However, there is little evidence that such shocks can elicit strong substitution effects on the trade balance. More specifically, a nominal devaluation may be followed by real depreciation and temporary improvement of the trade balance. The improvement is, nonetheless, more a result of expenditure reduction caused by output contraction than a result of expenditure switching.

In sum, the recent movements in China's trade balance are likely to persist in the future. A revaluation of the RMB, or a monetary measure in general, would not, in our view, suffice to redress the 'imbalance' of trade. 


\section{Appendix A The steady-state solution to the model}

The steady state is characterised by market-clearing in the non-tradables sector and balanced current account. Hence,

$$
\begin{aligned}
& \bar{C}_{N}=\bar{Y}_{N} \\
& \bar{C}_{T}=\bar{Y}_{T}-r^{*} \bar{D} .
\end{aligned}
$$

Among the first-order conditions of the optimisation problem (5)-(6) is the equality between the relative price of non-tradables to tradables and the ratio of the expected marginal utility of non-tradables consumption to that of tradables consumption. When perfect foresight prevails, that condition transpires as

$$
\frac{P_{N}}{P_{T}}=\left(\frac{1-\delta}{\delta}\right) \frac{\bar{C}_{T}}{\bar{C}_{N}}
$$

Intersectoral labour mobility equalises the wage rates in the two sectors. Along with profit maximisation, this implies that

$$
P_{T}\left(\alpha A_{T} L_{T}^{\alpha-1} \bar{K}^{1-\alpha}\right)=P_{N}\left(\beta A_{N} L_{N}^{\beta-1}\right)
$$

In the steady state, domestic capital and foreign assets are perfect substitutes since they earn the same rate of return, namely,

$$
r^{*}=(1-\alpha) A_{T} L_{T}^{\alpha} \bar{K}^{-\alpha}
$$

Substituting (A1), (A3) and (A4) into (A2) yields equation (11) and

$$
\log \bar{D}=\log \bar{K}=\Phi_{K}+\frac{1}{\alpha} a_{T}+\log \bar{\lambda}
$$

where $\Phi_{K}=(1 / \alpha-1)+\log L-1 / \alpha \log r^{*}$, and

$$
p_{T}-p_{N}=\Phi_{q}+\left(a_{N}-\frac{1}{\alpha} a_{T}\right)-(1-\beta) \log (1-\bar{\lambda})
$$

where $\Phi_{q}=\log \beta-\log \alpha-(1 / \alpha-1) \log (1-\alpha)-(1-\beta) \log L+(1 / \alpha-1) \log r^{*}$

Equation (10) follows directly from equations (8) and (A6), and equation (12) from equation (A5). 


\section{Appendix B Data and the results of unit-root tests}

The data used in this study are sourced primarily from China Monthly Statistics (CMS, various issues), published by the National Bureau of Statistics, and International Financial Statistics (IFS), published by the International Monetary Fund. Supplementary data sources are specified wherever they are used. The definitions, frequencies and sources of the series are as follows.

\begin{tabular}{|c|c|c|c|}
\hline Series & Definition & Frequency & Source \\
\hline Industrial production & gross industrial output at constant prices & monthly & $C M S$ \\
\hline Exports & $\begin{array}{l}\text { f.o.b. value of merchandise exports at } \\
\text { current US dollars }\end{array}$ & quarterly & IFS \\
\hline Imports & $\begin{array}{l}\text { c.i.f. value of merchandise imports at } \\
\text { current US dollars }\end{array}$ & quarterly & IFS \\
\hline REER & real effective exchange rate & quarterly & IFS \\
\hline Trade ratio & exports divided by imports & quarterly & $\begin{array}{l}I F S \text { and } \\
\text { author's }\end{array}$ \\
\hline Trade balance & exports minus imports & quarterly & calculation \\
\hline Foreign imports & $\begin{array}{l}\text { trade-weighted index of the imports } \\
\text { volumes of major trading partners }\end{array}$ & quarterly & \\
\hline
\end{tabular}

The monthly series of industrial production is converted to quarterly series by adding up the three monthly values for each quarter. The foreign imports series is calculated as the trade-weighted average of the imports volume indices of China's top sixteen trading partners. The IFS reports the index of imports volume for all of them except for Taiwan, Spain and Switzerland. The real imports of these three economies are obtained by deflating their imports value (in US dollars) by the US WPI. The real imports are then converted to index numbers with 1995 as the base year.

All series are seasonally adjusted with the X-11 procedure. They are then transformed by taking natural logarithms except the series of trade ratio and trade balance.

Three unit-root tests are performed on the series and the results are reported in Table A1. 
Table A1 Results of unit-root tests

\begin{tabular}{|c|c|c|c|c|c|c|c|}
\hline \multirow{2}{*}{ Variable $\left(x_{t}\right)$} & & \multicolumn{2}{|c|}{$\mathrm{ADF}^{\mathrm{a}}$} & \multicolumn{2}{|c|}{$\operatorname{PP}(I=3)^{b}$} & \multicolumn{2}{|c|}{$\operatorname{KPSS}(l=3)^{\mathrm{c}}$} \\
\hline & & $T_{\mu}$ & $T_{T}$ & $Z_{\mu}$ & $Z_{T}$ & $\eta_{\mu}$ & $\eta_{T}$ \\
\hline Industrial production & real & $-0.19(I=1)$ & $-2.05(I=2)$ & -0.17 & -2.13 & 1.69 & 0.15 \\
\hline Exports & nominal & $-1.38(I=4)$ & $-2.46(I=0)$ & -0.87 & -2.65 & 1.69 & 0.19 \\
\hline Imports & nominal & $-0.92(I=0)$ & $-2.60(I=0)$ & -0.90 & -2.63 & 1.64 & 0.13 \\
\hline Trade ratio (Ex/Im) & & $-1.46(I=0)$ & $-2.85(I=0)$ & -1.47 & -3.08 & 1.20 & 0.10 \\
\hline Trade balance (Ex-Im) & nominal & $-0.50(I=0)^{d}$ & $-1.00(I=0)^{\mathrm{e}}$ & $-0.19^{d}$ & $-0.71^{\mathrm{e}}$ & 1.31 & 0.12 \\
\hline Real effective exchange rate & & $-2.31(I=0)$ & $-3.75(I=0)$ & -2.30 & -3.58 & 1.00 & 0.35 \\
\hline Foreign imports & real & $-1.18(l=4)$ & $-3.33(l=4)$ & -0.64 & -2.14 & 1.68 & 0.19 \\
\hline
\end{tabular}

Notes: The sample period is Q1/1985-Q4/2000. Reported here are results concerning the levels of the series. The same tests have also been carried out on their first-differences. The results, available upon request, show that these series are stationary in first-differences.

a Augmented Dickey-Fuller test. Figures in parentheses are the number of lags included in the regressions. The lag lengths are chosen by adding lags until the Ljung-Box Q-statistics of order eight fails to reject no serial correlation at the $5 \%$ significance level. The critical values for $T_{\mu}$ at the $5 \%$ and $10 \%$ significance levels are -2.89 and -2.58 . Those for $\tau_{\tau}$ are -3.45 and -3.15 .

${ }^{\mathrm{b}}$ Phillips-Perron test. The bandwidth of the Bartlett kernel is chosen according to Newey and West (1987). The critical values for $Z_{\mu}$ and $Z_{T}$ correspond to those for $\tau_{\mu}$ and $\tau_{T}$ respectively.

c This test is proposed by Kwiatowski et al. (1992). The critical values for $\eta_{\mu}$ at the $5 \%$ and $10 \%$ significance levels are 0.463 and 0.347 . Those for $\eta_{\tau}$ are 0.146 and 0.119 .

$\mathrm{d}$ These are the test statistics from regressions with no deterministic components. The critical values at the $5 \%$ and $10 \%$ significance levels are -1.61 and -1.59 .

e These are based on regressions incorporating a constant only, that is, they are the test with $\tau_{\mu}\left(Z_{\mu}\right)$.

\section{References}

Agénor, P.R., McDermott, C.J., and Prasad, E.S. (2000) 'Macroeconomic fluctuations in developing countries: Some stylized facts'. The World Bank Economic Review 14: 251-85.

Ahearne, A.G., Fernald, J.G., and Loungani, P. (2001) 'Countering contagion: Does China's experience offer a blueprint?' Federal Reserve Bank of Chicago Economic Perspectives, 4th quarter: 38-52.

Bahmani-Oskooee, M. (1991) 'Is there a long-run relation between the trade balance and the real effective exchange rate of LDCs?' Economics Letters 36: 40-7.

Balassa, B. (1964) 'The purchasing power parity doctrine: A reappraisal'. Journal of Political Economy 72: 584-96. 
Bergstrand, J.H. (1991) 'Structural determinants of real exchange rates and national price levels: Some empirical evidence'. American Economic Review 81: 325-34.

Blanchard, O.J. and Quah, D. (1989) 'The dynamic effects of aggregate demand and supply disturbances'. American Economic Review 79: 655-73.

Bu, Y.X. and Tyers, R. (2001) 'China's equilibrium real exchange rate: a counterfactual analysis'. Working Papers in Economics and Econometrics No. 390, Australian National University: Canberra.

Campa, J.M. (2000) 'Exchange rates and trade: how important is hysteresis in trade?' CEPR Working Paper No. 2606, Centre for Economic Policy Research: London.

Cerra, V. and Dayal-Gulati, A. (1999) 'China's trade flows: changing price sensitivities and the reform process'. IMF Working Paper No. 99/01, Washington DC.

Chou, W.L. and Shih, Y.C. (1998) 'The equilibrium exchange rate of the Chinese Renminbi'. Journal of Comparative Economics 26: 165-174.

Dornbusch, R. (1988) Open Economy Macroeconomics, Basic Books: New York.

Edwards, S. (1986) 'Are Devaluations Contractionary?' Review of Economics and Statistics 68: 501-8.

Engel, C. (1999) 'Accounting for U.S. real exchange rate changes'. Journal of Political Economy 107: 507-38.

Frankel, J.A. and Rose, A. (1998) 'The Endogeneity of the Optimum Currency Area Criteria'. The Economic Journal 108: 1009-25.

Froot, K.A. and Rogoff, K. (1995) 'Perspectives on PPP and long-run real exchange rates'. In Handbook of International Economics vol. 3. G.M. Grossman and K. Rogoff (eds) North-Holland: Amsterdam.

Haynes, S.E. and Stone, J.A. (1982) 'Impact of the terms of trade on the U.S. trade balance: A reexamination'. Review of Economics and Statistics 64: 702-6.

Hoffmaister, A.W. and Roldós, J.E. (1999) 'Are business cycles different in Asia and Latin America?’ IMF Working Paper No. 97/9, Washington DC.

Hoffmaister, A.W. and Roldós, J.E. (2001) 'The sources of macroeconomic fluctuations in developing countries: Brazil and Korea'. Journal of Macroeconomics 23: 213-39.

Krugman, P. and Taylor, L. (1978) 'Contractionary effects of devaluation'. Journal of International Economics 8: 445-56.

Kwiatkowski, D., Phillips, P. C. B., Schmidt, P., and Shin, Y. (1992). 'Testing the null hypothesis of stationarity against the alternative of a unit root', Journal of Econometrics, 54: 159-78.

Liu, X.M., Wang, C.G., and Wei, Y.Q. (2001) 'Causal links between foreign direct investment and trade in China'. China Economic Review 12: 190-202.

Mendoza, E.G. (1995) 'The terms of trade, the real exchange rate, and economic fluctuations'. International Economic Review 36: 101-137.

Newey, W. and West, K. (1987). 'A simple, positive semi-definite, heteroskedasticity and autocorrelation consistent matrix', Econometrica, 55: 703-8. 
Parsley, D.C. and Wei, S.J. (1993) 'Insignificant and inconsequential hysteresis: The case of U.S. bilateral trade'. Review of Economics and Statistics 75: 606-13.

Polterovich, V. and Popov, V. (2002) 'Accumulation of foreign exchange reserves and long term economic growth'. Paper presented at 10th NES Anniversary conference. Moscow, December. Available at http://www.nes.ru/english/about/10thAnniversary/papers-pdf/Popov-Polterovich.pdf.

Prasad, E.S. (1999) 'International trade and the business cycle'. Economic Journal 109: 588-606.

Reinsel, G.C. and Ahn, S.K. (1992) 'Vector autoregressive models with unit roots and reduced rank structure: estimation, likelihood ratio test, and forecasting'. Journal of Time Series Analysis 13: 353-75.

Rogers, J.H. and Jenkins, M. (1996) 'Haircuts or hysteresis? Sources of movements in real exchange rates'. Journal of International Economics 38: 339-60.

Samuelson, P.A. (1964) 'Theoretical notes on trade problems'. Review of Economics and Statistics 46: 145-154.

Yue, C. and Hua, P. (2002) 'Does comparative advantage explains export patterns in China?' China Economic Review 13: 276-96.

Zellner, A. (1962) 'An efficient method of estimating seemingly unrelated regressions and tests for aggregation bias'. Journal of the American Statistical Association 57: 348-368.

Zhang, Z.C. (2001a) 'China's exchange rate reform and exports'. Economics of Planning 34: 89-112.

Zhang, Z.C. (2001b) 'Real exchange rate misalignment in China: An empirical investigation'. Journal of Comparative Economics 29: 80-94.

Zhang, Z.Y. (1996) 'The exchange value of the Reminibi and China's balance of trade: an empirical study'. NBER Working Paper No. 5771, NBER: Cambridge, MA. 